\title{
Empati Anak Usia 5-6 Tahun
}

\author{
Ani Sumarni ${ }^{1 *}$, Ari Sofia ${ }^{1)^{*}}$, Vivi Irzalinda1 ${ }^{\text {* }}$ \\ ${ }^{1}$ FKIP Universitas Lampung, J1. Prof. Dr. Soemantri Brojonegoro No.1 \\ e-mail: aniasiahansori@gmail.com
}

Abstract. Empathy of children in aged 5-6 years. The aims of the study to describe about the empathy of children in aged 5-6 years. The writer used descriptive quantitative method. The sample of the study was 41 children aged 5-6 years from Kindergarden in Segala Mider Village of Bandar Lampung which took by using purposive sampling. In collecting data the writer used observation. Analyzing the data was used descriptive analysis. The results showed that most of children had empathy in the low categori (4,46 percent).

Keywords: early childhood, empathy, the dimension of affection.

\begin{abstract}
Abstrak. Empati anak usia 5-6 tahun. Penelitian ini bertujuan untuk mendeskripsikan empati anak usia 5-6 tahun. Peneliti menggunakan metode penelitian deskriptif kuantitatif. Sampel penelitian diambil menggunakan purposive sampling sebanyak 41 anak usia 5-6 tahun di Taman Kanak-Kanak (TK) Kelurahan Segala Mider Kota Bandar Lampung. Teknik pengumpulan data yang digunakan yaitu observasi. Analisis data menggunakan analisis deskriptif. Hasil penelitian menunjukkan bahwa sebagian besar anak memiliki empati berada pada kategori rendah (41,46 persen).
\end{abstract}

Kata kunci : anak usia dini, empati. dimensi afeksi. 


\section{PENDAHULUAN}

Teknologi yang berkembang sangat pesat di era globalisasi saat ini memberikan keuntungan sekaligus kerugian bagi kelangsungan hidup manusia. Menurut Muthohar (2016) degradasi moral merupakan salah satu bentuk nyata dampak buruk dari kecanggihan teknologi tersebut.

Perilaku kekerasan sebagai bentuk degredasi moral nyatanya telah merebak diseluruh lapisan masyarakat termasuk dalam dunia anak. Komisi Perlindungan Anak Indonesia (KPAI) mencatat bahwa banyak kasus kekerasan yang terjadi melibatkan anak sejak tahun 2011-2018. Pada tahun 2011 terjadi sebanyak 2178 kasus, 2012 sebanyak 3512 kasus, 2013 sebanyak 4311 kasus, dan 2014 sebanyak 5066 kasus, 2015 sebanyak 4309 kasus, 2016 sebanyak 4622 kasus, 2017 sebanyak 4579 kasus, dan tahun 2018 sebanyak 4885 kasus.

Anak usia dini adalah individu yang sedang menjalani suatu proses pertumbuhan dan perkembangan dengan sangat pesat yangmana sangat dipengaruhi oleh lingkungan. Hal ini sejalan dengan pendapat Bronfrenbrenner (Rohinah, 2016) dalam teorinya tentang sistem ekologi menyatakan bahwa anak sangat dipengaruhi oleh lingkungan salah satunya lingkungan mikrosistem yang meliputi lingkungan keluarga anak, teman sebaya, sekolah, dan lingkungan tempat tinggal.

Pendidikan Anak Usia Dini (PAUD) merupakan salah satu lingkungan yang berpengaruh terhadap tumbuh kembang anak. PAUD merupakan bentuk penyelenggaraan pendidikan yang mengupayakan pemberian stimulus untuk pertumbuhan dan perkembangan baik jasmani maupun rohani kepada anak. Hal tersebut bermakna bahwa PAUD harus diselenggarakan secara terpadu dan komperhensif.

Empati merupakan salah satu aspek yang harus ditanamkan dengan optimal kepada anak sejak dini. Empati adalah kemampuan individu untuk memahami dan merasakan perasaan orang lain serta bereaksi secara tepat terhadap perasaan orang lain tersebut. Selanjutnya Borba (2008:21) menyatakan bahwa anak yang memiliki empati akan menunjukkan sikap toleransi, kasih sayang, memahami kebutuhan orang lain, mau membantu orang lain, pengertian, peduli, dan mampu mengendalikan amarahnya.

Berdasarkan penelitian pendahuluan peneliti pada bulan Oktober 2019 di TK Kelurahan Segala Mider menunjukkan bahwa empati anak usia 5-6 tahun masih rendah sehingga perlu dikembangkan kembali dengan optimal. Anak masih memaksakan kehendak kepada temannya, kurang mendengarkan temannya, mengganggu temannya, tidak membantu temannya, belum sabar menunggu antrian, mengabaikan temannya yang sedih, dan lupa meminta izin meminjam barang temannya.

Empati yang tinggi akan mendorong anak senantiasa memperlakukan orang lain dengan baik. Sementara disisi lain, rendahnya empati dapat mengakibatkan munculnya berbagai masalah sosial pada anak salah satunya bullying. Empati yang rendah akan memberikan peluang lebih besar bagi anak untuk melakukan bullying (Fatimatuzzahro \& Irwanto, 2017).

Bullying berdampak signifikan bagi fisik maupun psikologis anak sebagai pelaku maupun korban (Yandri, 2014). Bullying akan menghambat anak dalam mengaktualisasi dirinya, merasa minder, malu, luka fisik, ketakutan, depresi bahkan keinginan untuk bunuh diri (Maria \& Novianti, 2016). 
Empati sangat penting ditanamkan kepada anak sejak dini. Hal ini dikarenakan empati menjadi salah satu aspek yang berpengaruh bagi tumbuh kembang anak sekaligus juga menjadi pengontrol bagi anak untuk terhindari dari konflik sosial dan pengontrol dalam berprilaku baik terhadap orang lain sepanjang hidupnya.

Berdasarkan permasalahan di atas, peneliti mencoba untuk mengetahui bagaimana empati yang ditunjukkan oleh anak usia 5-6 tahun.

\section{METODE}

Desain penelitian ini adalah kuantitatif dengan metode deskriptif. Penelitian ini dilaksanakan di TK Kesuma dan Aisyiyah Bustanul Athfal 3 Kelurahan Segala Mider Kota Bandar Lampung. Waktu penelitian pada tahun ajaran 2019/2020.

Teknik pengumpulan sampel menggunakan purposive sampling. Sampel dipilih karena memenuhi jumlah sampel peneliti. Sampel juga merupakan TK berbasis islam yang mengembangkan pengetahuan juga perilaku beracu pada aturan islam. Sampel yang diambil sebanyak 41 anak di TK Kesuma kelompok B1 dan TK Aisyiyah Bustanul Athfal 3 kelompok B3.

Teknik pengumpulan data menggunakan observasi. Peneliti mengamati secara langsung empati anak usia 5-6 tahu. Pada penelitian ini peneliti hanya bertindak sebagai nonparticipatory observation.

Empati anak usia 5-6 tahun diukur dengan menggunakan instrumen yang dimodifikasi peneliti dari Borba (2008:21). Instrumen terdiri dari 22 butir pernyataan dengan 4 alternatif jawaban (4=sangat mampu, 3=mampu, 2=kurang mampu, dan 1=belum mampu). Hasil uji reliabilitas menunjukkan bahwa instrumen empati memiliki nilai Cronbach Alpha sebesar 0.965.

Skor masing-masing pernyataan dari variabel tersebut dijumlahkan dan diperoleh skor total dan kemudian masing-masing skor ditransformasikan ke dalam interval, dengan rumus sebagai berikut:

$$
\mathrm{I}=\frac{N T-N R}{K}
$$

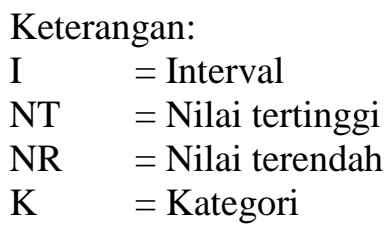

Data yang doperoleh tersebut dikelompokan menjadi lima kategori yaitu sangat rendah, rendah, sedang, tinggi, dan sangat tinggi. Pengkategorian tersebut mengacu pada pendapat Azwar (Sofia \& Adiyanti, 2014). Selanjutnya data yang diperoleh melalui observasi, dianalisis secara deskriptif.

\section{HASIL DAN PEMBAHASAN}

Berdasarkan hasil analisis diketahui bahwa persentase terbesar usia anak $(85 \%)$ berada pada kategori umur 6 tahun dan sisanya (15\%) berada pada kategori umur 5 tahun. Secara rinci dapat dilihat pada tabel 1 .

Tabel 1. Sebaran responden berdasarkan usia anak

\begin{tabular}{cccc}
\hline No & Kategori & n & $\%$ \\
\hline 1 & 5 tahun & 6 & 15 \\
2 & 6 tahun & 35 & 85 \\
\hline & Total & 41 & 100 \\
\hline
\end{tabular}

Sementara sebaran lain pada responden berdasarkan jenis kelamin menyatakan bahwa responden yang berjenis kelamin perempuan sebanyak $(61 \%)$ dan sisanya laki-laki sebanyak 
(39\%). Secara rinci dapat dilihat pada tabel 2.

Tabel 2. Sebaran responden berdasarkan jenis kelamin

\begin{tabular}{cccc}
\hline No & Kategori & n & \% \\
\hline 1 & Laki-laki & 16 & 39 \\
2 & Perempuan & 25 & 61 \\
\hline & Total & 41 & 100 \\
\hline
\end{tabular}

Hasil analisis menunjukkan bahwa sebagian besar responden memiliki skor empati sebesar 41,46 persen berada pada kategori rendah. Jika dipilah berdasarkan kategori, sebaran responden yang memiliki skor empati berada pada kategori sangat rendah sebanyak 21,95 persen. Selain itu, sebanyak 36,59 berada pada kategori sedang dan 0,00 persen responden memiliki skor empati berada pada kategori tinggi dan sangat tinggi. Secara rinci dapat dilihat pada tabel 3.

Tabel 3. Sebaran responden berdasarkan kategori empati

\begin{tabular}{|c|c|c|c|c|}
\hline No & Kategori & Interval & $\mathbf{n}$ & $\%$ \\
\hline 1 & $\begin{array}{l}\text { Sangat } \\
\text { rendah }\end{array}$ & $26<X \leq 38$ & 9 & 21,95 \\
\hline 2 & Rendah & $39<X \leq 51$ & 17 & 41,46 \\
\hline 3 & Sedang & $52<X \leq 64$ & 15 & 36,59 \\
\hline 4 & Tinggi & $65<X \leq 77$ & 0 & 0,00 \\
\hline 5 & $\begin{array}{l}\text { Sangat } \\
\text { tinggi }\end{array}$ & $78<X \leq 90$ & 0 & 0,00 \\
\hline \multicolumn{3}{|c|}{ Total } & 41 & 100 \\
\hline
\end{tabular}

Adapun hasil penelitian dari tiap dimensi empati yaitu toleransi, kasih sayang, menolong orang lain, peduli, dan mampu mengendalikan amarahnya. Hasil penelitian dimensi toleransi menunjukkan bahwa sebagian besar responden memiliki skor dimensi toleransi berada pada kategori sedang (48,78 persen).

Tabel 4. Sebaran responden berdasarkan kategori dimensi toleransi

\begin{tabular}{lllll}
\hline No & Kategori & Interval & n & $\%$ \\
\hline
\end{tabular}

\begin{tabular}{clccc}
\hline No & Kategori & Interval & n & \% \\
\hline 1 & Sangat & $6<\mathrm{X} \leq 8$ & 3 & 7,32 \\
& rendah & & & \\
2 & Rendah & $9<\mathrm{X} \leq 11$ & 12 & 29,27 \\
3 & Sedang & $12<\mathrm{X} \leq 14$ & 20 & 48,78 \\
4 & Tinggi & $15<\mathrm{X} \leq 17$ & 6 & 14,63 \\
5 & Sangat & $18<\mathrm{X} \leq 20$ & 0 & 0,00 \\
& tinggi & & & \\
\hline \multicolumn{3}{c}{ Total } & 41 & 100 \\
\hline
\end{tabular}

Sementara hasil penelitian dimensi kasih sayang menunjukkan bahwa sebagian besar responden memiliki skor dimensi kasih sayang berada pada kategori sedang (39,02 persen).

Tabel 5. Sebaran responden berdasarkan kategori dimensi kasih sayang

\begin{tabular}{clccc}
\hline No & Kategori & Interval & n & \% \\
\hline 1 & Sangat & $5<\mathrm{X} \leq 7$ & 6 & 14,63 \\
& rendah & $8<\mathrm{X} \leq 10$ & 8 & 19,51 \\
2 & Rendah & $11<\mathrm{X} \leq 13$ & 16 & 39,02 \\
3 & Sedang & $14<\mathrm{X} \leq 16$ & 9 & 21,95 \\
4 & Tinggi & & \\
5 & Sangat & $17<\mathrm{X} \leq 19$ & 2 & 4,88 \\
\hline \multicolumn{7}{r}{ tinggi } & & 41 & 100 \\
\hline
\end{tabular}

Selanjutnya hasil penelitian dimensi menolong orang lain menunjukkan bahwa sebagian besar responden memiliki skor dimensi menolong orang lain berada pada kategori rendah $(48,78$ persen).

Tabel 6. Sebaran responden berdasarkan kategori dimensi menolong orang lain

\begin{tabular}{clccc}
\hline No & Kategori & Interval & n & $\%$ \\
\hline 1 & Sangat & $5<\mathrm{X} \leq 7$ & 8 & 19,51 \\
& rendah & $8<\mathrm{X} \leq 10$ & 20 & 48,78 \\
2 & Rendah & $11<\mathrm{X} \leq 13$ & 11 & 26,83 \\
3 & Sedang & $14<\mathrm{X} \leq 16$ & 2 & 4,88 \\
4 & Tinggi & 0 & 0,00 \\
5 & Sangat & $17<\mathrm{X} \leq 19$ & 0 & 100 \\
\hline \multicolumn{5}{c}{ tinggi } \\
\hline \multicolumn{5}{c}{ Total } \\
Hasil penelitian dimensi & peduli
\end{tabular}
menunjukkan bahwa sebagian besar responden memiliki skor dimensi peduli 
berada pada kategori sedang $(56,10$ persen).

Tabel 7. Sebaran responden berdasarkan kategori dimensi peduli

\begin{tabular}{|c|c|c|c|c|}
\hline No & Kategori & Interval & $\mathbf{n}$ & $\%$ \\
\hline 1 & $\begin{array}{l}\text { Sangat } \\
\text { rendah }\end{array}$ & $4<X \leq 5$ & 3 & 7,32 \\
\hline 2 & Rendah & $6<X \leq 7$ & 12 & 29,27 \\
\hline 3 & Sedang & $8<X \leq 9$ & 23 & 56,10 \\
\hline 4 & Tinggi & $10<\mathrm{X} \leq 11$ & 3 & 7,32 \\
\hline 5 & $\begin{array}{l}\text { Sangat } \\
\text { tinggi }\end{array}$ & $12<X \leq 13$ & 0 & 0,00 \\
\hline
\end{tabular}

Terakhir hasil penelitian dimensi mengendalikan amarah menunjukkan bahwa sebagian besar responden memiliki skor dimensi mengendalikan amarah berada pada kategori sedang (48,78 persen).

Tabel 8. Sebaran responden berdasarkan kategori dimensi mengendalikan amarah

\begin{tabular}{|c|c|c|c|c|}
\hline \multirow{2}{*}{$\frac{\text { No }}{1}$} & Kategori & Interval & $\mathrm{n}$ & $\%$ \\
\hline & $\begin{array}{l}\text { Sangat } \\
\text { rendh }\end{array}$ & $3<X<4$ & 3 & 7.32 \\
\hline 2 & Rendah & $5<X \leq 6$ & 9 & 21,95 \\
\hline 3 & Sedang & $7<X \leq 8$ & 20 & 48,78 \\
\hline 4 & Tinggi & $9<\mathrm{X} \leq 10$ & 9 & 21,95 \\
\hline \multirow[t]{2}{*}{5} & $\begin{array}{l}\text { Sangat } \\
\text { tinggi }\end{array}$ & $11<\mathrm{X} \leq 12$ & 0 & 0,00 \\
\hline & Tota & & 41 & 100 \\
\hline
\end{tabular}

Selanjutnya dimensi di atas dijabarkan dalam 22 item. Secara rinci dapat dilihat pada tabel 9 .

Tabel 9. Sebaran responden berdasarkan item empati ( $\mathrm{F}=41)$

\begin{tabular}{lcc}
\hline \multicolumn{1}{c}{ Item } & M & SD \\
\hline Toleransi & 11,98 & 2,33 \\
A1 & 2,12 & 0,52 \\
A2 & 2,34 & 0,70 \\
A3 & 2,16 & 0,50 \\
A4 & 1,99 & 0,69 \\
A5 & 3,36 & 0,51 \\
Kasih sayang & 11,02 & 3,44 \\
B6 & 1,25 & 0,48
\end{tabular}

\begin{tabular}{lcc}
\hline \multicolumn{1}{c}{ Item } & M & SD \\
\hline B7 & 2,84 & 0,97 \\
B8 & 2,51 & 1,21 \\
B9 & 2,71 & 0,90 \\
B10 & 1,71 & 0,66 \\
Menolong & 9,08 & 2,09 \\
C11 & 1,70 & 0,67 \\
C12 & 1,77 & 0,62 \\
C13 & 1,17 & 0,32 \\
C14 & 2,38 & 1,06 \\
C15 & 2,07 & 0,66 \\
Peduli & 7,43 & 1,36 \\
D16 & 1,12 & 0,27 \\
D17 & 1,40 & 0,48 \\
D18 & 3,34 & 0,74 \\
D19 & 1,58 & 0,57 \\
Mengendalikan & 6,76 & 1,43 \\
amarah & & \\
E20 & 2,17 & 0,43 \\
E21 & 2,43 & 0,53 \\
E22 & 2,16 & 0,55 \\
\hline
\end{tabular}

\section{Pembahasan}

Hasil penelitian menunjukkan bahwa sebagian besar anak usia 5-6 tahun di TK Kelurahan Segala Mider memiliki skor empati berada pada kategori rendah (41,46 persen). Hal ini sejalan dengan penelitian pendahuluan oleh Wulandari, Rosidah, \& Maryani (2017:163) dan Iis (2012:1) bahwa empati anak usia 5-6 tahun masih berada pada kategori rendah.

Hasil penelitian diatas merupakan proses yang wajar dialami anak. Menurut Sujiono (2013:6) bahwa anak usia 5-6 tahun adalah anak yang sedang menjalani proses pertumbuhan dan perkembangan. Anak masih belajar berempati dengan orang lain. Selanjutnya Piaget (Suryana, 2014:7) menyatakan bahwa anak usia 5-6 tahun sedang berada pada fase praoperasional egosentris untuk perkembangan kognitifnya.

Dimensi toleransi menunjukkan sebagian besar anak memiliki skor pada kategori sedang. Anak menyalimi guru saat pulang sekolah merupakan perilaku 
yang sebagian besar mampu dilakukan anak. Hal ini disebabkan karena kebiasaan yang selalu diterapkan guru. Sejalan dengan itu, Khaironi (2017:5) menyatakan bahwa anak belajar berprilaku baik dari kebiasaan yang selalu diterapkan orang dewasa disekitarnya. Semantara, perilaku anak meminta maaf kepada orang lain merupakan perilaku yang sebagian besar belum mampu dilakukan anak. Hal ini sejalan dengan penelitian lis (2012:5) bahwa anak masih belum mau meminta maaf ketika melakukan kesalahan.

Dimensi kasih sayang menunjukkan sebagian besar anak memiliki skor pada kategori sedang. Anak membalas salam orang lain merupakan perilaku yang sebagian besar sangat mampu dilakukan anak. Hal ini disebabkan contoh yang ditunjukan guru. Kohn (1991:501) dan Kremer \& Dietzen (1991:69) bahwa guru mengajarkan empati dengan memodelkan perilaku empatik. Sementara, perilaku anak yang memberikan semangat kepada temannya yang merasa sedih sebagian besar belum mampu dilakukan anak. Menurut Limarga (2017:93) anak kurang paham kapan harus mendekati dan membiarkan temannya yang sedih.

Dimensi menolong orang lain menunjukkan sebagian besar anak memiliki skor pada kategori rendah. Anak berbagi makanan sebagian besar sangat mampu dilakukan anak. Hal ini disebabkan beberapa hal salah satunya pola asuh orang tua (Suyadi dan Maulidya, 2013:149; Sofia \& Adiyanti, 2014:138). Sementara, anak membantu temannya yang kesulitan mengerjakan tugas sebagian besar belum mampu dilakukan anak.

Dimensi peduli menunjukkan sebagian besar anak memiliki skor pada kategori sedang. Perilaku anak yang membuang sampah pada tempatnya sebagian besar sangat mampu dilakukan anak. Menurut Puspita (2010:211) anak mencontoh perilaku tesebut dari orang dewasa disekitarnya. Sejalan dengan itu, Denham (Borba, 2008:38) menyatakan bahwa anak akan mencontoh perilaku orang tuanya sehingga orang tua yang berempati akan membuat anak lebih berempati pula. Sementara, perilaku anak yang menghampiri temannya yang sedang mengalami kesulitan menyelesaikan tugasnya sebagian besar belum mampu dilakukan anak.

Dimensi mengendalikan amarah menunjukkan sebagian besar anak memiliki skor pada kategori sedang. Anak sabar menunggu antrian mengambil alat tulis sebagian besar mampu dilakukan anak. Sementara, perilaku anak yang sabar menunggu antrian mengambil alat main sebagian besar kurang mampu dilakukan anak. Menurut Sujiono (2013:121) anak masih pada fase egosentris, dimana anak masih memahami sesuatu dari sudut pandang dan kepentingan pribadinya.

Masa dini merupakan masa yang tepat untuk membangun empati anak. Hal ini sejalan denga penelitian Perry (Borba, 2008:20) bahwa tiga tahun pertama merupakan masa penting dalam hidup anak untuk membangun empati. Selanjutnya Borba (2008:25) menyatakan ada tiga langkah yang dapat dilakukan untuk menumbuhkan empati anak yaitu membangkitkan kesadaran dan perbendaharaan ungakapan emosi, meningkatkan kepekaan terhadap perasaan orang lain, dan mengembangkan empati terhadap sudut pandang orang lain.

Empati yang berkembang dengan baik akan bermanfaat baik bagi kehidupan anak selanjutnya. Menurut Davis (Howe, 2015:324) empati akan membantu anak untuk terhindar dari konflik sosial dan berprilaku baik. Manfaat lain juga disampaikan oleh 
Safaria (Sarah, 2018:12) bahwa empati membantu anak untuk menghilangkan sikap egois (mementingkan diri sendiri) serta menghilangkan sikap sombong.

\section{SIMPULAN}

Berdasarkan hasil analisis dapat disimpulkan bahwa sebagian besar usia anak berada pada rentang usia 6 tahun. Sebagian besar jenis kelamin anak adalah perempuan. Persentase terbesar responden memiliki skor empati pada kategori rendah.

Berdasarkan kesimpulan, penelitian ini memberikan saran antara lain bagi orang tua, diharapkan menumbuhkan komitmen yang tinggi dan kesadaran yang penuh bahwa empati sangat bermanfaat sehingga mampu mencontohkan dan menanamkan kebiasaan berprilaku baik sejak dini. Bagi guru, diharapkan memberikan saran terbaik dan membantu meningkatkan kesadaran orang tua serta mengambil langkah dalam menanamkan empati anak sejak dini. Bagi kepala sekolah, diharapkan dapat meningkatkan kerja sama dengan guru untuk menanamkan empati sejak dini dalam lingkungan yang tepat dengan optimal. Bagi peneliti selanjutnya, diharapkan dapat mengembangkan penelitian ini dengan meneliti lebih lanjut terkait empati anak usia dini serta dikaitkan dengan usia dan jenis kelamin anak, sehingga data yang diperoleh dapat lebih mendalam.

\section{REFERENSI}

Borba, Michele. (2008). Membangun Kecerdasan Moral. PT Gramedia Pustaka Utama: Jakarta.

Fatimatuzzahro, A., Suseno, M. N., \& Irwanto, B. (2017). Efektivitas Terapi Empati untuk Menurunkan Perilaku Bullying pada Anak Usia Sekolah Dasar. Jurnal Petik: 3(2), 1-12.
Howe, David. (2015). Empati: Makna dan Pentingnya. Pustaka Belajar: Yogyakarta.

Iis, N. (2012). Pengembangan Empati Anak Usia Dini melalui Mendongeng di Taman KanakKanak Asyiyah Pariaman. Jurnal Ilmiah Pesona PAUD: 1(4).

Khaironi, M. (2017). Pendidikan Moral pada Anak Usia Dini. Jurnal Golden Age: 1(01), 1-15.

Kohn, A. (1991). Caring Kids, The Role of The Schools. Phi Delta Kappan: 72(7), 496-506.

Komisi Perlindungan Anak Indonesia. (2019). KPAI Sebut Pelanggaran Hak anak terus Meningkat. Https://www.kpai.go.id/berita/kpaisebut-pelanggaran-hak-anak-terusmeningkat. Diakses 2 Januari 2020.

Kremer, J. F., \& Dietzen, L. L. (1991). Two Approaches to Teaching Accurate Empathy to Undergraduates: Teacher-Intensive and Self-Directed. Journal of College Student Development: 32(1), 69-75.

Limarga, D. M. (2017). Penerapan Metode Bercerita dengan Media Audio Visual untuk Meningkatkan Kemampuan Empati Anak Usia Dini. Tunas Siliwangi: Jurnal Program Studi Pendidikan Guru PAUD STKIP Siliwangi Bandung: 3(1), 86-104.

Maria, I., \& Novianti, R. (2016). Pengaruh Pola Asuh dan Bullying terhadap Harga Diri (Self Esteem) pada Anak Kelompok B Tk di Kota Pekanbaru Tahun 2016. Jurnal Educhild: Pendidikan dan Sosial, 6(1), 61-69.

Muthohar, S. (2016). Antisipasi Degradasi Moral di Era Global. Nadwa: 7(2), 321-334.

Puspita, W. A. (2010). Pendidik Pendidikan Anak Usia Dini (Paud) 
sebagai Model Perilaku Anak Usia Dini. Jurnal Ilmiah Visi: 5(2), 209215.

Rohinah, R. (2016). Parenting Education sebagai Model Pendidikan Karakter Anak Usia Dini Berbasis Keluarga. Golden Age: Jurnal Ilmiah Tumbuh Kembang Anak Usia Dini: 1(1), 27-37.

Sarah, Dwi Mai. (2018). Studi Deskriptif Perilaku Empati Siswa terhadap Lingkungan Sosial Sekolah di MI Muhammadiyah Sidamulya Kemranjen. (Skripsi). Universitas Muhammadiyah Purwokerto, Jawa Tengah.

Sofia, A., \& Adiyanti, M. G. (2014). Hubungan Pola Asuh Otoritatif Orangtua dan Konformitas Teman Sebaya terhadap Kecerdasan Moral. Jurnal Ilmu Pendidikan: 4(2), 133-141.

Sujiono, Yuliani Nuraini. (2013). Konsep Dasar Pendidikan Anak Usia Dini. PT Indeks: Jakarta.

Suryana, Dadan. (2014). Dasar-Dasar Pendidikan TK. Universitas Terbuka: Jakarta.

Suyadi dan Maulidya Ulfah. (2013). Konsep Dasar PAUD. Rosdakarya: Bandung.

Wulandari, F., Rosidah, L., \& Maryani, K. (2017). Meningkatkan Kemampuan Berempati Anak Usia 5-6 Tahun melalui Cooperative Learning. Jurnal Ilmiah Visi: 12(2), 163-169.

Yandri, H. (2014). Peran Guru BK/Konselor dalam Pencegahan Tindakan Bullying di Sekolah. Jurnal Pelangi: 7(1). 